\title{
Teaching and Assessment Methods: STEM Teachers' Perceptions and Implementation
}

\author{
Effrat Akiri ${ }^{1 *}$, Hrisilda Matathia Tor ${ }^{2}$, Yehudit Judy Dori ${ }^{1,3}$ \\ ${ }^{1}$ Faculty of Education in Science and Technology, Technion, Israel Institute of Technology, Haifa 3200003, ISRAEL \\ 2 Yonatan Netanyahu Secondary School, Kyriat Motzkin 2643011, ISRAEL \\ 3 The Samuel Neaman Institute for National Policy Research, Haifa 3200003, ISRAEL
}

Received 14 January 2021 - Accepted 18 March 2021

\begin{abstract}
This study explores Science, Technology, Engineering and Mathematics (STEM) teachers' perceptions of teaching and assessment methods. We investigated 125 STEM subject coordinators and teachers using interviews and questionnaires. We examined the most commonly implemented teaching and assessment methods, and the reasons teachers chose them. Then, we compared teachers from different school levels, subjects, teaching experience and cultural backgrounds. The teaching methods implemented the most were lectures and presentations, followed by class discussions and collaborative classwork. The most implemented assessment method was tests with open- and closed-ended questions, followed by project portfolios and experiment reports. Subject coordinators preferred methods that integrate formative assessment more than teachers. The study contributes to a better understanding of the teaching and assessment methods implemented in schools and the gap between recommendations and actual implementation. Conducted prior to the COVID-19 pandemic, this research sets a baseline for similar future post-COVID research.
\end{abstract}

Keywords: active learning, perceptions, formative assessment, in-service teachers, interactive teaching, STEM teachers

\section{INTRODUCTION}

A wide set of Science, Technology, Engineering and Mathematics (STEM) skills is required for students to succeed in contemporary industry, environment, and society. These skills include scientific inquiry, analysis, teamwork, argumentation, critical thinking, problem solving, innovation, creativity, and technological and scientific literacy (Kohen et al., 2020; Miedijensky, \& Tal, 2009; Tsybulsky, 2018; Usher \& Barak, 2020; Zohar \& Nemet, 2002). Teaching and assessment methods have been found to be associated with the development of STEM skills (Hodgson et al., 2014; Worlitz et al., 2018; Zezekwa \& Nkopodi, 2020). Teachers are expected to adapt their teaching methods to include $21^{\text {st }}$ century skills and to impart them to their students (Bennett \& Hogarth, 2009; Darling-Hammond et al., 2014; Lavi et al., 2021; Ropohl \& Rönnebeck, 2019; Westbroek et al., 2020). However, even though teachers are expected to engage students in active learning processes, they often assess their students' progress using traditional assessment tools that measure knowledge more than skills. In many cases, the expectations and recommendations of OECD and the National Research Council (NRC) do not coincide with actual implementation (Howells, 2018; NRC, 2012).

Israeli science curriculum requirements include alternative teaching methods such as inquiry, which is taught gradually, starting with guided inquiry and progressing to open-ended inquiry. Case-based learning involves the incorporation of narratives of authentic problems from the students' everyday life. In ProjectBased Learning (PBL), learning is based on authentic problems, and the student is required to produce an artifact. Solving algorithmic problems, which have a single solution, does not fulfill these requirements.

This study explores the perceptions of STEM subject coordinators and teachers of various teaching and 


\section{Contribution to the literature}

- We explored Science, Technology, Engineering and Mathematics (STEM) teachers' perceptions of various teaching and assessment methods based on 125 participants from different school levels, subjects of teaching, experience, and cultures.

- High school teachers preferred collaborative and open teaching methods, while middle school teachers preferred individual assignments. Differences can be explained by the matriculation examinations, which require that $30 \%$ of the material be graded based on authentic assignments, inquiry projects, and portfolios.

- The research is unique in that it compares a wide array of 14 teaching methods and eight assessment methods and the reasons the teachers preferred to implement them.

assessment methods, as a school's commitment to STEM education is influenced by the STEM coordinators' motivation and perceptions (Aslam et al., 2018). We refer to teaching methods that are more teacher-centered as traditional ones, and methods that are more studentcentered as interactive teaching methods. In this paper, assessment methods are referred to as either traditional (e.g., test and quiz), formative/alternative (e.g., experiment reports and project portfolios), or assessment for learning (Avargil et al., 2013; Deeley, 2018; Dori et al., 2018). Whereas prior research has focused mostly on forms of interactive teaching and alternative assessment in primary and middle schools (Gale et al., 2016; Zlabkova et al., 2020), interactive teaching and alternative assessment methods have received less scholarly attention in the context of STEM secondary education (Gozuyesil \& Tanriseven, 2017; Grob et al., 2019). Our goal in this study is to investigate the STEM subject coordinators' and teachers' perceptions of various teaching and assessment methods. Our research questions are:

(1) With respect to STEM teaching and assessment methods:

a. What methods do the participants implement as a group?

b. What are the subject coordinators' and teachers' perceptions of teaching and assessment methods? What differences are there, if any, between the perceptions of these two research groups?

c. What reasons did teachers provide for adopting and implementing the various teaching and assessment methods?

(2) What are the similarities and differences in the implementation of teaching and assessment methods within the following subgroups:

a. Primary, middle school, and high school teachers.

b. Science and mathematics teachers.

c. Teachers with different amounts of teaching experience.

d. Majority and minority groups.

\section{RESEARCH BACKGROUND}

In this paper, traditional teaching methods refer to use of digital presentations, lectures and white boards, films, and other methods that do not require the student's active involvement. These methods are considered teacher-centered (Schwerdt \& Wuppermann, 2011).

Interactive teaching methods are non-traditional methods that require the students' active engagement, as they set their own pace and control their learning (Rees \& Roth, 2019; Soldano \& Arzarello, 2016; Tal et al., 2006). Interactive methods encourage students to learn through experience. They are considered student-centered teaching methods, and are more aligned with the constructivist theory for fostering meaningful and active learning (Akkus et al., 2007).

Interactive teaching methods include (1) projectbased learning; (2) inquiry-based learning; (3) content or context-based learning; (4) teamwork; and (5) class discussions. The benefits of these particular methods have been presented in several studies (Barak \& Raz, 1998; Barron \& Darling-Hammond, 2008; Eskilsson \& Hellden, 2003; Gilbert, 2006; Karpudewan et al., 2011; Marušić, \& Sliško, 2012; Mills \& Treagust, 2003; Schallies \& Eysel, 2004). Some interactive teaching methods, such as project-based assessment, inherently include alternative assessments (Dori Y. J., 2003; Krajcik et al., 1994; Tal et al., 2006).

Assessment can be a powerful tool for learners, particularly when integrated into the learning process. For decades, standardized assessment has been the main way of assessing students (Aitken, 2016). Standardized assessments are tests that can consist of open-ended questions, or closed-ended ones such as multiple-choice questions. These tests are given to a predefined population group. An entire group - a class, school, applicants, etc. - takes the same standardized test, which mostly measures knowledge at different levels of complexity. However, these tests are limited in their measuring capability and pose certain difficulties (Hebel et al., 2017). School teachers generally assess their students in order to grade their performance at the end of the term. 
Over the last two decades, researchers have been trying to develop new ways of measuring students' skills using what is known as 'formative' or 'alternative' assessment. Formative assessment, also known as assessment for learning, has been shown to enhance students' skills and competence (Avargil et al., 2013; Birenbaum \& Breuer, 2006; Mandler et al., 2012; Russ et al., 2008). Alternative assessment refers to any nonstandardized methods. They are usually more tailored to the individual as part of the learning process, and are not used only to measure students' knowledge and comprehension (Haug \& Ødegaard, 2015; Miedijensky, \& Tal, 2009; Neumann, 2015; Rached \& Grangeat, 2020).

Teachers are advised to use alternative assessment methods in addition to traditional tests (Ropohl \& Rönnebeck, 2019; Stender et al., 2018). Alternative assessment methods are more accountable than summative assessment when interactive teaching takes place, such as in the case of project-based learning (Chetcuti \& Cutajar, 2014; Havnes et al., 2012; Namdar \& Shen, 2015; Wiliam, 2011).

This study explored the perceptions of two research groups - STEM subject coordinators and STEM teachers - regarding teaching and assessment methods commonly implemented by teachers, in an attempt to understand if there is a gap between recommendations and actual implementation.

Subject coordinators are the link between management and teachers. They are critical for the success of educational reforms (Farchi \& Tubin, 2016). To ensure their success, they receive up-to-date, subjectspecific training, and apply their skills in their schools (Moore, 1992). The perceptions and beliefs of subject coordinators and teachers are crucial factors for selecting teaching and assessment methods. Effective and engaging teaching and assessment methods can ultimately improve students' STEM-related perceptions and skills. Even so, teachers often use teaching or assessment methods for other reasons, subject to constraints related to school policies, time limitations, and availability. Some factors that affect students' motivation to pursue STEM education and careers are related to their teachers, their gender, and their social or cultural settings. Therefore, students' interest, motivation, and perceptions would most likely improve if learning took place in an environment tailored to their needs and interests. This could be achieved by implementing a combination of teaching and assessment methods that create an interactive learning environment and an active learning atmosphere (Anghelache, 2013; Marchis, 2011; Stollman et al., 2020; Wang X., 2013).

Keeping up to date with technology is a significant challenge for schools. Most of the schools in Israel are equipped with only one computer lab for the whole school and a single computer in each classroom. This limits teachers' ability to implement technology-based interactive teaching and alternative assessment methods, and creates technological literacy gaps between students (Ertmer, 1999; Foon Hew \& Brush, 2007; Osborne, 2014).

In the school setting, standard assessment refers to the standardized tests given to students throughout the school year to determine their grades at the end of each term (Aitken, 2016; Harlen \& James, 2006). Students are assessed for various reasons, such as to measure their knowledge, encourage learning, measure the effectiveness of the curriculum, and more. Interactive learning methods should be accompanied by accountable assessment that coincides with the implemented teaching method (Grob et al., 2019; Wieman, 2014; Wiliam et al., 2004).

\section{Cultural and Societal Differences}

Middle school and high school science teachers' experiences differ with regard to assessment, knowledge, and students' motivation. In high school, teachers are expected to prepare students for the matriculation examinations given towards graduation, and they adapt their assessment methods accordingly. Middle school teachers' assessment of students' knowledge is aligned with specific school policies and National Standardized tests such as PISA ${ }^{1}$. For this reason, middle school teachers are less inclined to implement changes and reforms. Most high school STEM teachers hold a B.A. in a specific STEM field and are usually very discipline-oriented, as opposed to middle school teachers whose education is usually more general and who teach science as a broad and more interdisciplinary subject. High schools STEM classes are usually majors chosen by the students, while middle school students are required to study a predefined set of subjects (disciplines) and are sometimes less motived to study a specific subject (Lesseig et al., 2016; Liu et al., 2020).

In many cases, science and mathematics departments are encouraged to work closely together to improve students' skills (Berlin \& Lee, 2005). Science studies have been shown to be dependent on mathematics, but this dependence is not necessarily symmetrical (Wong, 2018). New technologies provide innovative learning opportunities, which teachers are encouraged to integrate (Barabash, 2019; Dori et al., 2020; Kop et al., 2020). Yet, although mathematics teachers try to engage in student-centered methods, they still tend to prefer teacher-centered methods, despite the fact that studentcentered methods largely determine students' performance (Muema et al., 2018; Umugiraneza et al., 2017).

1 https://www.oecd.org/pisa/ 
Table 1. Participants' demographics

\begin{tabular}{llllll}
\hline Participants & Role & Gender & Sector & School & Experience \\
\hline Interviews & Subject coordinators & Male & Majority & Middle school & Novice \\
$(\mathrm{N}=9)$ & $45 \%$ & $11 \%$ & $78 \%$ & $78 \%$ & $45 \%$ \\
& Teachers & Female & Minorities & High school & Experienced \\
& $55 \%$ & $89 \%$ & $22 \%$ & $22 \%$ & $55 \%$ \\
\hline Questionnaires & Subject coordinators & Male & Majority & Primary & Novice (1-4 years) \\
$(\mathrm{N}=116)$ & $41 \%$ & $20 \%$ & $76 \%$ & $14 \%$ & $28 \%$ \\
& Teachers & Female & Minorities & Middle school & Experienced (5-15 years) $44 \%$ \\
& $59 \%$ & $80 \%$ & $24 \%$ & $26 \%$ & Experts (>15 years) \\
\hline
\end{tabular}

Teachers' experience has been shown to correlate with their perceptions of learning (Copur-Gencturk \& Thacker, 2020). Novice teachers tend to focus mostly on navigating a classroom and the demands of teaching, though they are expected to plan interesting lessons (Fairbanks et al., 2000). It has also been found that teachers' experience influences their reactions to new reforms (Avargil et al., 2013; Liu et al., 2020).

Researchers of STEM education have explored the attitudes of STEM teachers toward teaching and assessment methods. For example, biology teachers had positive attitudes toward assessment for learning, but there was no significant difference between their attitudes toward traditional assessment and their attitudes toward assessment for learning (Bramwell et al., 2016; Hofstein et al., 2012; Juuti et al., 2010). The researchers usually focus on either subject coordinators or teachers, emphasize one discipline, and discuss only perceptions of one or two types of teaching or assessment methods. We examined and compared the perceptions of both subject coordinators and teachers toward various teaching and assessment methods, and investigated the differences among majority and minority STEM teachers. In Israel, most of the minorities are Arab speakers. Arab teachers usually teach in Arabic-speaking schools, and Jewish teachers teach in Hebrew-speaking schools (Gindi \& Erlich-Ron, 2019). This presents a challenge for STEM studies, as most of the science learning materials are available only in Hebrew (Barnea et al., 2010). Another difference between minorities and the majority group is cultural norms. Arab culture is traditional oriented and is commonly characterized by strong family systems (Toren \& Iliyan, 2008). Questioning authority is discouraged, and the teacher is considered the authoritative source of knowledge. Hence, questioning and criticism are often considered unacceptable and disrespectful (Abd-El-Khalick, et al., 2004). Resources in Arab schools are also limited, and classrooms in some schools have fewer technological tools than their Jewish counterparts (Nachmias et al., 2010; Sedawi et al., 2019).

\section{METHODOLOGY}

The study was designed based on an exploratory, sequential, mixed-methods approach, in which qualitative data collection was followed by a quantitative analysis (Creswell, 2014; Leech \& Onwuegbuzie, 2009). Interviews with the participants provided data that created the basis for collecting additional data using a questionnaire. The questionnaire included closed- and open-ended questions. This gave us the opportunity to triangulate the data provided by the participants, hence increasing the validity of our findings, and strengthening our interpretations of these findings (Golafshani, 2003).

\section{Participants}

Participants ( $\mathrm{N}=116)$ were STEM teachers and subject coordinators from high, middle, and primary schools who represented both gender and sector groups. Interviewees ( $\mathrm{N}=9$ ) and questionnaires' respondents represented a diverse population (see Table 1). Participants were recruited via social media and during professional development workshops.

The participants' mean age was 39.6 (10.1). The distribution resembled that of the general teacher population, according to the Central Bureau of Statistics (Buchnik et al., 2014). The subject coordinators in this research (and in most of the schools in Israel) are also STEM teachers themselves. When teachers reported teaching more than one subject, we chose the subject with more teaching hours as the teacher's discipline.

\section{Data Collection and Analysis}

The data was collected over the course of a year, prior to the COVID-19 pandemic.

\section{Research instruments}

The research instruments included interviews and questionnaires. The first stage involved interviews that were designed to address teaching and assessment methods that are relevant for STEM subject coordinators and teachers. The interviews were 30-60 minutes long and included the following questions: What teaching 
Table 2. Teachers' perception factors

\begin{tabular}{|c|c|c|c|}
\hline Factor & Statement example & $\begin{array}{c}\mathrm{N} \text { of } \\
\text { items }\end{array}$ & $\begin{array}{l}\text { Alpha } \\
\text { Cronbach }\end{array}$ \\
\hline $\begin{array}{l}\text { Perceptions towards alternative } \\
\text { teaching and assessment methods }\end{array}$ & $\begin{array}{l}\text { In the school I teach at, the students can influence the way in } \\
\text { which they are assessed }\end{array}$ & 9 & 0.853 \\
\hline $\begin{array}{l}\text { Perceptions towards passive teaching } \\
\text { methods and traditional assessment }\end{array}$ & $\begin{array}{l}\text { In my opinion, traditional assessment methods (standardized } \\
\text { tests) are better and more efficient }\end{array}$ & 7 & 0.612 \\
\hline Available resources in the schools & $\begin{array}{l}\text { In the school I teach at, most classes are equipped with a computer } \\
\text { for the teacher }\end{array}$ & 5 & 0.606 \\
\hline Total & & 21 & 0.759 \\
\hline
\end{tabular}

and assessment methods are most common in your practice? Why are these methods the most common? Explain. The data gathered during the interviews were used to create a list of teaching and assessment methods to be ranked by all the participants who responded to the questionnaires.

\section{Development of research instrument}

The first version of the questionnaire was developed based on the literature (Akkus et al., 2007; Barak \& Shakhman, 2008; Birenbaum \& Breuer, 2006; Hodgson et al., 2014; Juuti et al., 2010; Worlitz et al., 2018). We extended the questions based on the interviews with the aim of including a wider variety of teaching and assessment methods. The first version of the questionnaire included 30 open- and closed-ended questions. Later, after a factor analysis (see Appendix A), the questions were reduced once more to 28 questions.

To validate the questionnaire, we administered it to 28 chemistry and science teachers who participated in a chemistry education training program. The final version of the questionnaire consisted of 29 open- and closedended questions, in which the participants were asked to select the most commonly implemented teaching and assessment methods in their classes from a predefined list, with the option of adding additional methods. The list of teaching methods included lectures, demonstrations, class discussions, and inquiry-based learning. The list of assessment methods included standardized tests with open- and closed-ended questions, laboratory experiments and writing lab reports, and end-of-year inquiry portfolios. The teaching and assessment methods are described in detail in the Findings section. After choosing the methods they tend to implement, participants were asked why they chose these methods over the others. The questionnaire also included 22 Likert scale questions, aimed at understanding the teachers' perceptions and resources. We conducted factor analysis of these questions and identified three factors, as shown in Table 2.

One of the questions was eliminated. Full factor loading is presented in Appendix A: Factor loadings for participants' perceptions towards teaching and assessment methods and school resources.
The qualitative part of the questionnaire, in which teachers explained the reasons for their choices, was analyzed based on the categories that arose from the content analysis of the interviews.

The diversity of the questions, which enabled triangulation of the data provided by the participants with their perceptions of the teaching and assessment methods they use in their classrooms, further validated the findings (Golafshani, 2003).

\section{Data collection}

The questionnaire was distributed to the participants via email, Facebook, WhatsApp, in professional development workshops, and by personal requests. Most participants selected two or three methods. In total, 390 teaching methods and 239 assessment methods were selected by the 116 respondents.

\section{Data analysis}

To address the first research question, we used descriptive statistics to identify the methods most commonly implemented. We used a chi square test to compare subject coordinators' and teachers' preferences for each method, and t-tests to compare their perceptions of alternative and traditional teaching and assessment methods. The reasons given by the teachers were analyzed using content analysis.

To answer the second research question, we used ttests and ANOVA analysis, as well as content analysis of the qualitative data.

\section{FINDINGS}

The findings presented in this section are based on data collected prior to the COVID-19 pandemic, which forced major changes worldwide, and particularly in education systems. Findings are presented in response to the research questions. To address the first research question, we analyzed the teachers' and subject coordinators' perceptions. We first present the participants' perceptions toward teaching methods, which were divided into the categories of passive teaching, interactive teaching, and teaching methods that incorporate formative assessment methods. We then highlight the differences between subject coordinators and teachers. This is followed by presenting 
Table 3. Teaching methods most often used by teachers $(\mathrm{N}=116)$

\begin{tabular}{|c|c|c|}
\hline Category & Teaching method & Percent [\%] N=116 \\
\hline \multirow[t]{4}{*}{ Passive teaching methods } & Lecture & 48.3 \\
\hline & Presentations & 41.4 \\
\hline & Short videos & 22.4 \\
\hline & Demonstrations & 15.5 \\
\hline \multirow[t]{3}{*}{ Interactive teaching methods } & Class discussion & 41.4 \\
\hline & Collaborative class work & 37.9 \\
\hline & Computerized learning & 12.1 \\
\hline \multirow{4}{*}{$\begin{array}{l}\text { Teaching methods combining formative assessment - } \\
\text { also referred to as assessment for learning }\end{array}$} & Experiments & 34.5 \\
\hline & Worksheets & 25.9 \\
\hline & Inquiry-based learning & 15.5 \\
\hline & Project-based learning (PBL) & 6.9 \\
\hline
\end{tabular}

participants' choices regarding assessment, grouping the assessment methods according to traditional and formative, and then highlighting the differences between the groups. Finally, we present the reasons given by the participants for adopting these methods and how these reasons are distributed between the categories. To address the second research question, the similarities and differences between the subgroups are presented, including specific examples from the qualitative data.

\section{Perceptions toward Teaching Methods}

The full list of teaching methods and percentages of teachers who selected each method are presented in Table 3. Shaded cells represent methods selected more frequently.

As shown in Table 3, the preferred teaching methods are lectures and presentations, followed by class discussions and collaborative classwork. Case-based learning, after school collaborative work and educational tours, are interactive teaching methods that were selected by less than $6 \%$ of the participants, and therefore were not included in the data analysis. Only three participants $(1.8 \%)$ chose to add other teaching methods such as private lessons or WhatsApp communication.

When comparing subject coordinators' and teachers' choices, only PBL was found to significantly differ between the two groups $\left(\chi^{2}=12.17, p<0.001\right)$, as $16.7 \%$ of subject coordinators selected this method, compared to none of the teachers. It should be noted that high school science teachers involved in PBL often refer to this method as inquiry portfolio, as this type of alternative assessment is required as part of the evaluation process for students who chose to major in biology, chemistry, or physics. The subject coordinators selected teaching methods that incorporate assessment in 33\% of the cases, while teachers selected these methods in only $22 \%$ of all cases. Teachers chose traditional methods in $46 \%$ of all cases, compared to $38 \%$ among subject coordinators.

In the interviews, both the subject coordinators and teachers expressed positive perceptions of most of the teaching methods. All the participants expressed a positive perception of traditional teaching methods, except for a highly experienced principal of a middle school. When asked which teaching methods she thought should be integrated in the classroom and about guidelines she gives the teachers in her school, she answered that "...the children will ask questions and conduct inquiry projects, while the teacher serves as a mentor, s/he is not in the center of the class, s/he tutors ... The children should learn through experience". She did not mention any traditional teaching methods, and expressed a positive opinion toward interactive teaching.

Three of the subject coordinators and two of the teachers we interviewed had very positive perceptions of interactive teaching methods and of methods that incorporate assessment for learning (particularly inquiry, experiment reports, projects, and computerized teaching). Only the teacher with the least experience had negative views about interactive teaching methods: "... and many times, this is what I experienced this year, I really wanted to do something different, not conventional, and it caused the students to lose focus".

In the open-ended questions, many teachers explained that they use lectures and presentations to introduce new material, and use discussions, independent work, and teamwork for practice.

\section{Perceptions toward Assessment Methods}

Table 4 presents the full list of assessment methods, the participants' selections, and example quotes that explain the reasons given by the participants. Shaded cells represent methods selected more frequently than others.

As shown in Table 4, the most implemented assessment methods were standardized tests with openand closed-ended questions, standardized tests with open-ended questions, experiment reports, and project portfolios.

Use of standardized tests with open- and closedended questions was the only assessment method found to significantly differ between subject coordinators and teachers $\left(\chi^{2}=7.71, p<0.01\right)$, as $72.9 \%$ of subject coordinators selected this method, compared to $47.1 \%$ of the teachers. 
Table 4. Assessment methods used most by teachers $(\mathrm{N}=116)$

\begin{tabular}{|c|c|c|c|}
\hline Category & Assessment method & $\begin{array}{l}\text { Percentage [\%] } \\
\quad \mathrm{N}=116\end{array}$ & Quote \\
\hline \multirow[t]{3}{*}{$\begin{array}{l}\text { Traditional } \\
\text { assessment }\end{array}$} & $\begin{array}{l}\text { Standardized tests with open- ended and } \\
\text { closed-ended questions }\end{array}$ & 57.8 & Reflects the knowledge of all the student levels in class \\
\hline & $\begin{array}{l}\text { Standardized tests with open-ended } \\
\text { questions }\end{array}$ & 33.6 & $\begin{array}{l}\text { A standard method, familiar/known to students and their } \\
\text { parents }\end{array}$ \\
\hline & $\begin{array}{l}\text { Standardized tests with closed-ended } \\
\text { questions }\end{array}$ & 12.1 & Easy to evaluate, students are familiar with it \\
\hline \multirow{5}{*}{$\begin{array}{l}\text { Alternative } \\
\text { assessment }\end{array}$} & Experiment report & 25.0 & The report enables evaluating knowledge and skills \\
\hline & Project portfolio & 24.1 & $\begin{array}{l}\text { The portfolio is a multi-stage, group effort that indicates } \\
\text { the student's attitude and creativity }\end{array}$ \\
\hline & Inquiry portfolio & 15.5 & $\begin{array}{l}\text { Enables development of several skills, according to the } \\
\text { child's specific talents and levels of understanding }\end{array}$ \\
\hline & Computerized assessment & 11.2 & $\begin{array}{l}\text { Computerized assessment is a very convenient method for } \\
\text { monitoring and evaluating students. The children tend to } \\
\text { participate more while using their smartphones }\end{array}$ \\
\hline & Oral tests & 8.6 & They depend on their own words and need to work hard \\
\hline
\end{tabular}

In response to the open-ended questions, most of the participants expressed very positive or positive perceptions of traditional assessment methods: "I don't think that there is anything wrong with tests, if there was, I wouldn't use them.". The only exception was a middle school principal: "...we are used to thinking that standard assessment is easier to quantify... a test doesn't offer a good experience for the student, input-output, ... ". Although she stated that a standardized test does not summon a positive experience for the student, she acknowledged that this kind of assessment is easier to conduct. Four of the subject coordinators we interviewed had very positive perceptions of alternative assessment methods: "the advantage of alternative assessment is that they [the students] will remember what they did in the long run... you can make them love what they do". The fourth subject coordinator expressed a neutral or ambivalent attitude toward alternative assessment methods: "If the plan is to use alternative assessment there are a lot of factors to consider... When the students work at home you cannot be sure who did the work; family members could intervene". Even though most subject coordinators had a very positive approach toward alternative assessment methods, they acknowledged the advantages of standardized assessment as being very quick, short, and mostly providing a good representation of the students' knowledge and abilities.

T-tests were used to investigate differences between perceptions of subject coordinators and of teachers. Differences in the perceptions of alternative teaching and assessment methods between subject coordinators $(\mathrm{M}=3.96, \mathrm{SD}=0.52)$ and teachers $(\mathrm{M}=3.46, \mathrm{SD}=0.71)$ were found to be significantly different, $t(113.879)=4.128$, $\mathrm{p}<0.01$. No significant differences were found between these groups with respect to perceptions of both traditional teaching and assessment methods and the available resources that teachers have in their schools.

\section{Reasons for Method Selection}

We categorized and quantified the reasons given for selecting the implemented methods, based on the qualitative data gathered from the open-ended questions in the questionnaires. Most of the explanations focused on students' (95\%) or teachers' (91\%) abilities. The full list of reasons is presented in Table 5 .

The second research question addresses cultural differences between different groups of teachers. We will present comparison data from the following groups: (a) primary, middle school, and high school teachers; (b) science vs. mathematics teachers; (c) teachers with different levels of experience in teaching; and (d) teachers from majority vs. minority groups. We analyzed all participants, and referred to all of them as teachers since the subject coordinators are also teachers, and despite nuances, there were almost no differences between the groups.

Figures 1-4 present the distribution of the participants who selected each of the teaching and assessment methods as the ones that are most implemented in their classes, according to the criteria defined.

\section{Similarities and Differences - School Level}

Figure 1 presents the most implemented teaching and assessment methods at the school level - primary, middle, and high school. 
Table 5. Reasons for implementation of methods*

\begin{tabular}{|c|c|c|c|}
\hline $\begin{array}{l}\text { Reason for the selected } \\
\text { preference }\end{array}$ & $\begin{array}{l}\text { Frequencies of } \\
\text { statements }(\%)\end{array}$ & Example statements & $\begin{array}{l}\text { The method that the } \\
\text { teacher referred to }\end{array}$ \\
\hline Students' abilities & $95 \%$ & $\begin{array}{l}\text {...students preferred this [assessment] method [standardized tests], } \\
\text { because it requires less work from them. }\end{array}$ & standardized tests \\
\hline Teachers' abilities & $91 \%$ & $\begin{array}{l}\text { In recent years, I've been teaching only with multidisciplinary } \\
\text { projects, I don't believe in anything else. }\end{array}$ & $\begin{array}{l}\text { Multidisciplinary } \\
\text { projects }\end{array}$ \\
\hline \multirow[t]{2}{*}{$\begin{array}{l}\text { Characteristics of the } \\
\text { method }\end{array}$} & $91 \%$ & $\begin{array}{l}\text {...because the [PBL] requires a prolonged process and the } \\
\text { development of a product and more involvement. On the other } \\
\text { hand, they leave more room for individual interpretation. }\end{array}$ & PBL \\
\hline & & Using class discussion enables dialogical teaching & Class discussion \\
\hline \multirow[t]{2}{*}{$\begin{array}{l}\text { Ministry of Education } \\
\text { guidelines }\end{array}$} & $52 \%$ & $\begin{array}{l}\text {...experiments, because they're mandatory according to the } \\
\text { Ministry of Education, and because they're fun. }\end{array}$ & Experiment \\
\hline & & Inquiry is part of the chemistry program... & Inquiry \\
\hline \multirow[t]{6}{*}{$\begin{array}{l}\text { Challenges } \\
\text { for teachers }\end{array}$} & $52 \%$ & $\begin{array}{l}\text {...because the of the lack of computers and laboratories, I don't have } \\
\text { many options. }\end{array}$ & $\begin{array}{l}\text { Computers and } \\
\text { laboratories }\end{array}$ \\
\hline & & $\begin{array}{l}\text { We don't have fieldtrips because our school location and budget } \\
\text { issues. }\end{array}$ & Fieldtrips \\
\hline & $38 \%$ & $\begin{array}{l}\text { Inquiry - although I am very supportive of this method, I find it } \\
\text { difficult to apply, because of the syllabus of the course and the tight } \\
\text { schedule. }\end{array}$ & Inquiry \\
\hline & & I lecture when I don't have enough time & Lecture \\
\hline & $35 \%$ & I don't have enough training in the constructivist method. & $\begin{array}{l}\text { Constructivist } \\
\text { methods }\end{array}$ \\
\hline & & $\begin{array}{l}\text { The students write questions, I create an exam based on questions I } \\
\text { selected from that pull, and afterwards, I write the answer on } \\
\text { Padlet so it's available to everyone }\end{array}$ & $\begin{array}{l}\text { Tests based on } \\
\text { students pull }\end{array}$ \\
\hline \multirow[t]{2}{*}{ Subject matter } & $21 \%$ & Fieldtrips are not suitable for teaching mathematics. & Fieldtrips \\
\hline & & \multicolumn{2}{|c|}{$\begin{array}{l}\text { Mathematic don't leave much room for many teaching methods, so ITraditional methods } \\
\text { use lectures for explaining and teamwork for practice. }\end{array}$} \\
\hline
\end{tabular}

${ }^{*}$ Dark grey indicates high frequency while no color represents low frequency of the teachers' reasoning

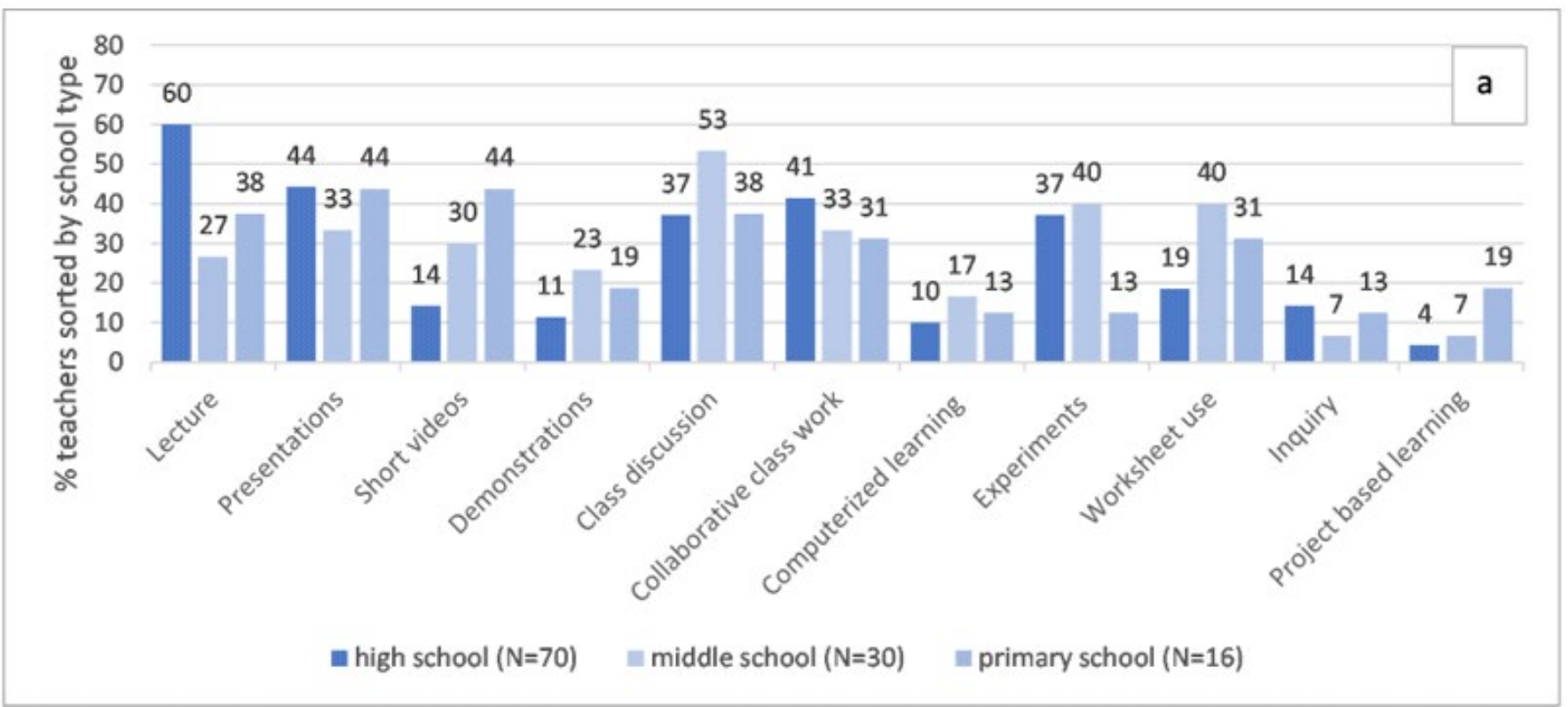

Figure 1. Teaching methods (a) and assessment methods (b) that are most implemented in primary, middle, and high schools

*A Standardized Test - ST 


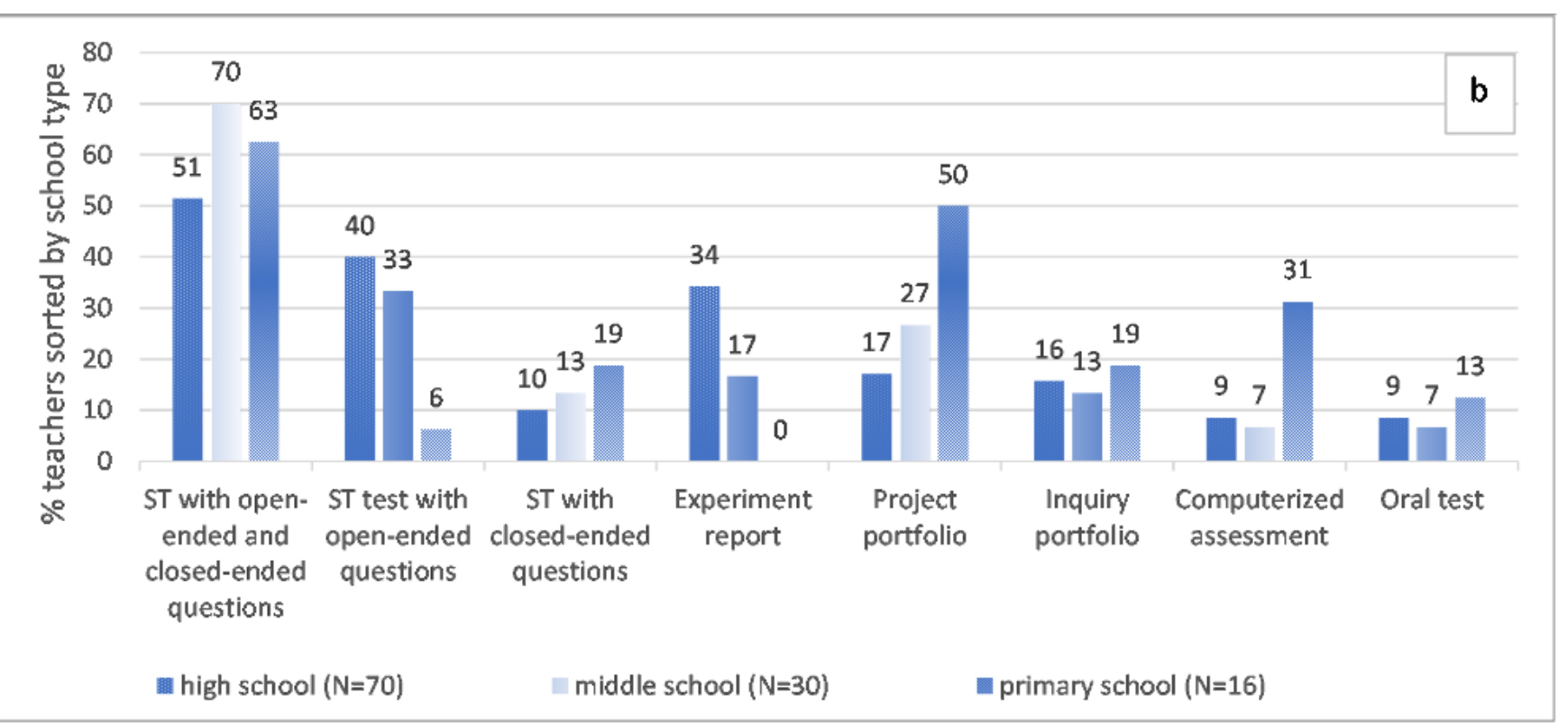

Figure 1 (continued). Teaching methods (a) and assessment methods (b) that are most implemented in primary, middle, and high schools

*A Standardized Test - ST

As shown, high school teachers use lectures, presentations, and collaborative class work, more often than experiments. Middle school teachers chose class discussions as their most used method, followed by worksheets and experiments. A high school mathematics and physics teacher explained: "Anything that doesn't serve the matriculation examinations, the students see as a waste of time, as they are involved in many other social activities." [1122023212026]. Primary school teachers ranked presentations and short videos equally, followed by lectures and class discussions, also at the same frequency. As a primary school mathematics teacher wrote: "Short movies are stimulating and intriguing, questions are asked, and conclusions are drawn. PBL helps construct the knowledge, as the students face a task, and the teacher guides them by asking questions." [1112041511035].

It appears that tests with open- and closed-ended questions are used by all teachers, many of whom stated that they use tests only to comply with system requirements. High school and middle school teachers' second choice was tests with open-ended questions, while primary school teachers' second choice was project portfolios, followed by computerized assessment. Few primary school teachers selected tests with open-ended questions and experiment reports, but they did choose a variety of other assessment methods. As one teacher explained, "this enables the student to express the knowledge he has acquired in different ways and opens several paths towards success." [1112033411079].

With respect to perceptions regarding available resources teachers have in their schools, one-way ANOVA revealed a significant difference $(\mathrm{F}=4.44$, $\mathrm{p}<0.05)$ between primary school teachers $(\mathrm{M}=4.6$, $\mathrm{SD}=0.45)$ and high school teachers $(\mathrm{M}=4.2, \mathrm{SD}=0.62)$.
Primary school teachers' perceptions of alternative teaching and assessment methods as well as traditional teaching and assessment methods did not differ significantly from the perceptions of their high school peers.

\section{Similarities and Differences - Subject}

A comparison between mathematics teachers and science teachers revealed differences that can be associated with the demands of the subjects they teach, as shown in Figure 2.

Mathematics teachers tend to use lectures, class discussions, and worksheets. Science teachers use experiments, presentations, and lectures, in that order. Mathematic teachers use worksheets to the same extent that science teachers use experiments. One mathematics teacher stated that "students want and need to practice by themselves or in groups." [2122011311069]. A science teacher said: "When a student conducts an experiment independently, he experiences meaningful learning and has higher chances of remembering [the process]." [1212112411064].

Regarding assessment, mathematics teachers prefer tests with open-ended questions, while science teachers' first choice was tests with open- and closed-ended questions. Other than tests, mathematics teachers selected project portfolios, while science teachers selected experiment reports. A science teacher explained that "open- and closed-ended questions on tests and experiment reports enable evaluating the students in the most correct way and offer the best opportunities for success and curiosity." [1211042411066].

A t-test conducted to compare mathematics and science teachers revealed significant differences related 


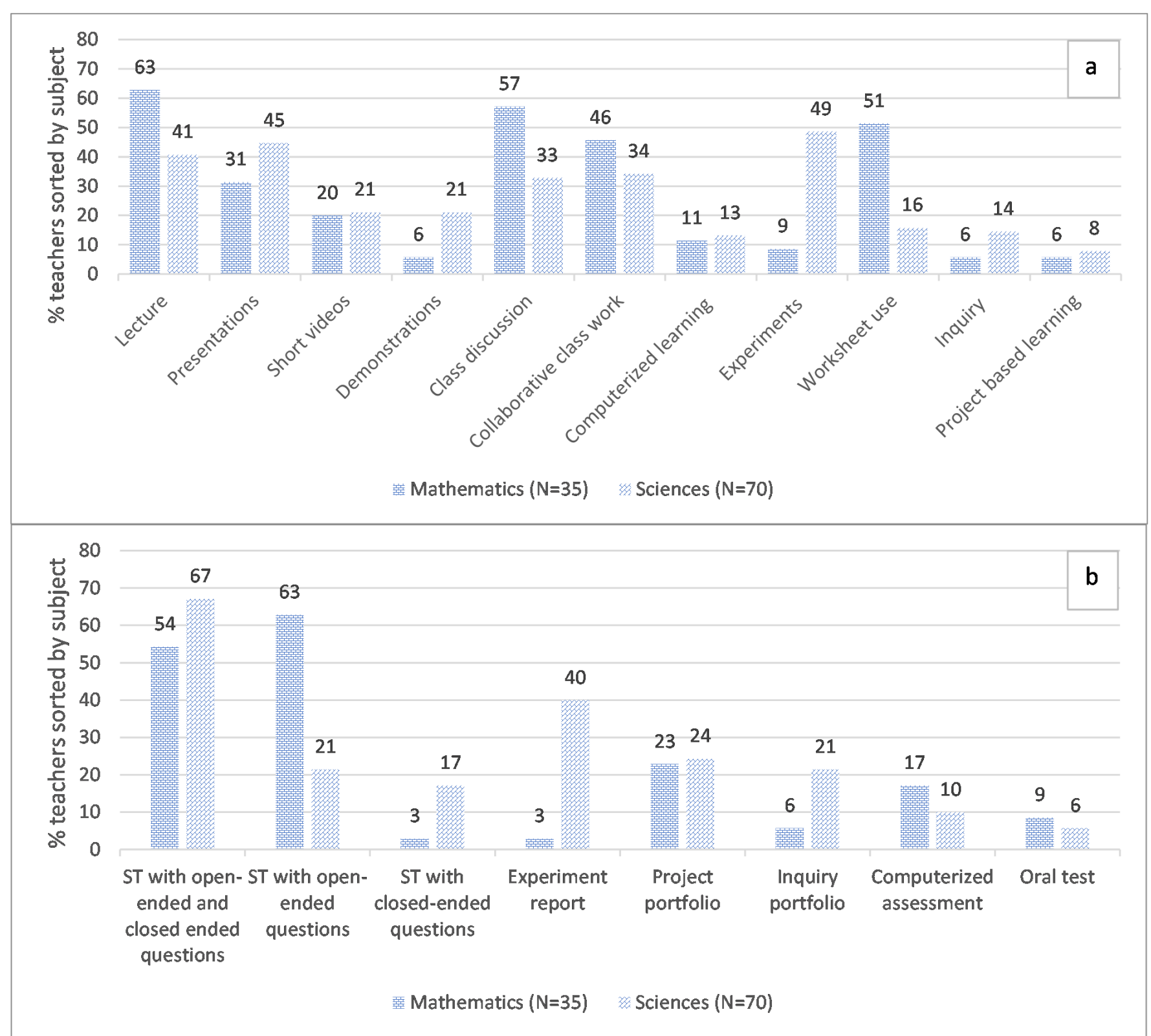

Figure 2. Teaching methods (a) and assessment methods (b) that are most implemented by science and mathematics teachers

* Standardized Test - ST

to their perceptions of alternative teaching and assessment methods, $t(60.774)=-3.05, p<.01$, and their perceptions of traditional teaching and assessment methods, $t(109)=2.14, p<.05$. Mathematics teachers reported more negative perceptions of alternative teaching and assessment methods $(\mathrm{M}=3.36, \mathrm{SD}=0.7)$ than science teachers $(\mathrm{M}=3.79, \mathrm{SD}=0.63)$. Mathematics teachers reported more positive perceptions of traditional teaching and assessment methods $(\mathrm{M}=3.38$, $\mathrm{SD}=0.52)$ than science teachers $(\mathrm{M}=3.16, \mathrm{SD}=0.48)$. No significant difference was found with respect to the resources available to teachers in their schools.

\section{Similarities and Differences - Teaching Experience}

Seniority was divided into three categories: novice (14 years), experienced (5-15), and expert (more than 15 years), as shown in Figure 3.

Novice teachers use presentations and lectures: "in lectures I teach the material." [2322112311033]. Experienced teachers selected lectures as their first choice, and preferred class discussions over presentations. As one experienced teacher stated, "discussions just happen in class all the time, I ask questions or the children do, and it goes in many directions." [2222133411024]. The expert teachers selected both class discussions and experiments as their first choice. Hence, collaborative class work was chosen by both novice and expert teachers in over $40 \%$ of the responses. An expert 


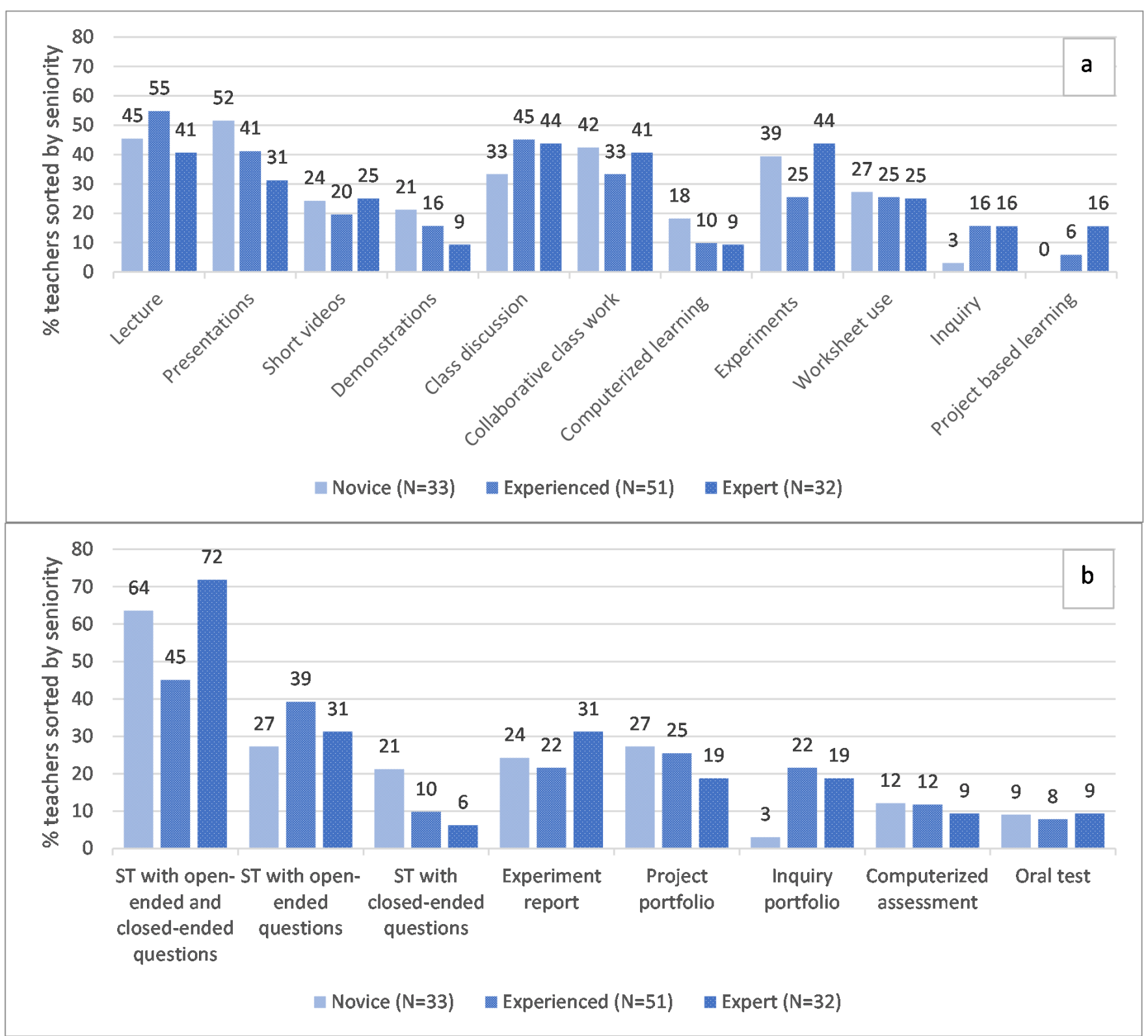

Figure 3. Teaching methods (a) and assessment methods (b) that are most implemented by novice, experienced, and expert teachers

* Standardized Test - ST

teacher said that "in collaborative class work, the students learn from each other, are involved in studying, reinforce their knowledge while explaining to their friends, and improve the class atmosphere." [2222040511104].

Regarding assessment, all the teachers selected standardized tests with open- and closed-ended questions, regardless of seniority.

No significant differences in perceptions were found between teachers with different degrees of teaching experience.

\section{Similarities and Differences - Teachers' Culture}

The final comparison was done between teachers from majority and minority groups, as shown in Figure 4.
Teachers from the majority group used lectures and class discussions, while teachers from minorities used lectures and collaborative classwork. As one of the Arab teachers wrote, "working in small groups to solve problems is very helpful and allows me to walk among the students and help where needed." [2322012221013]. Presentations were ranked third place by both groups.

Standardized tests with open- and closed-ended questions were the most implemented assessment method for both groups. Project portfolios and openended questions were in second place in the majority group, and the minority group ranked experiment reports in third place. Computerized assessment and oral examinations differed as well. A teacher from the majority group stated that "computerized assessment is easy to control and evaluate." [2212110311097], but none of 


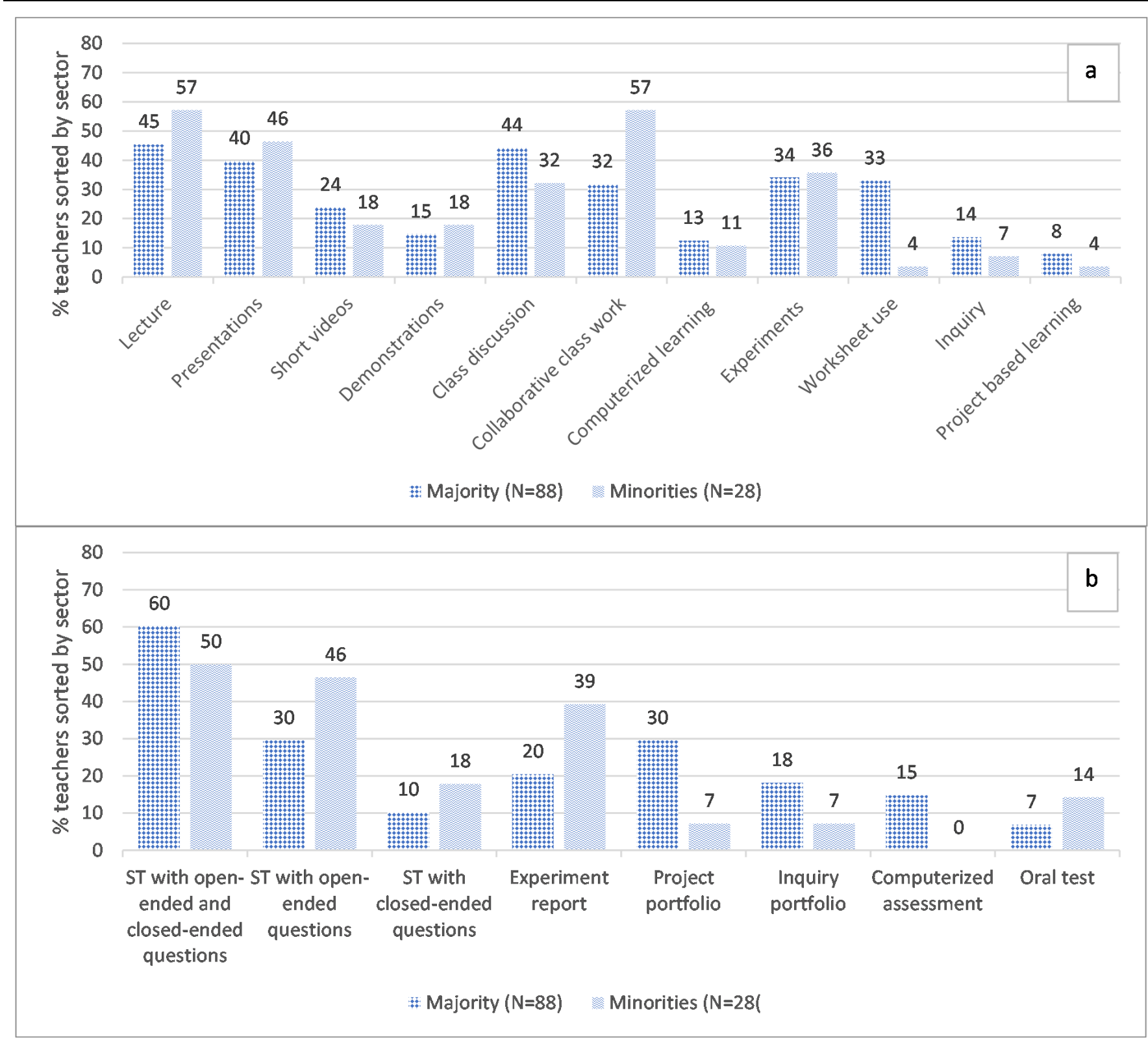

Figure 4. Teaching methods (a) and assessment methods (b) that are most implemented by teachers in majority and minority groups

* Standardized Test - ST

the teachers from the minority group selected this method of evaluation.

No significant differences were found between teachers from the majority and minority groups with respect to perceptions of alternative teaching and assessment methods and perceptions of traditional teaching and assessment methods, but a borderline difference, $t(114)=1.73, p=.85$, was found with respect to available resource teachers have in their schools. Teachers from the majority group reported higher availability of resources $(\mathrm{M}=4.37, \mathrm{SD}=0.55)$ than teachers from the minority group $(\mathrm{M}=4.15, \mathrm{SD}=0.65)$.

\section{DISCUSSION}

Different methods have unique characteristics that can be advantages or disadvantages, depending on circumstances such as time resources, student heterogeneity, teamwork, and epistemic knowledge; external issues such as school conditions; and intrinsic issues such as teachers' perceptions.

In this study, we explored STEM subject coordinators' and teachers' perceptions of teaching and assessment methods. We analyzed how cultural differences influence the methods applied based on teachers' roles, schools, subjects, experience (novice, experienced, or expert), and sector. Most teachers reported implementation of more traditional methods. Lectures, used by $48.3 \%$ of the participants, were the most common teaching method. Closely behind, with $41.4 \%$ of the participants, were digital presentations and class discussions. Despite NRC recommendations that students productively participate in science learning, 
two of the three most common methods implemented by the participants do not require the students to be active during class, and class discussions often engage a very small percentage of the students (NRC, 2012).

The most common assessment method was standardized tests with open- and closed-ended questions, followed by tests with open-ended questions, experiment reports, and project portfolios. This may indicate that there is a certain understanding of the need to conduct assessment for learning along with assessment of learning (Birenbaum et al., 2006).

Most reasons given by teachers to explain why they did not select the methods recommended by the Ministry of Education were related to lack of resources or training. Insufficient support for teachers on using alternative assessment methods might explain its minimal implementation, as alternative assessment requires considerable support and professional development for teachers (Avargil et al., 2012; Haug \& Ødegaard, 2015; Westbroek et al., 2020).

\section{Subject Coordinators and Teachers' Perceptions and Reasoning}

Subject coordinators selected teaching methods that combine formative assessment, also referred to as assessment for learning, more frequently than teachers, who preferred traditional teaching methods. It seems that teachers are more hesitant to adopt continuous, progressive teaching methods that incorporate assessment. This hesitation may be due to the teachers' lower self-efficacy compared to that of the STEM subject coordinators. Self-efficacy can influence teachers' beliefs and decision-making processes regarding implementation of innovative educational methods (Evers et al., 2002; Zee \& Koomen, 2016). Subject coordinators receive up-to-date training as part of their managerial role, and therefore they are usually more confident (Farchi \& Tubin, 2016; Moore, 1992).

Most of the participants had ambivalent or negative perceptions of alternative assessment methods than of interactive teaching methods. Most of the teachers avoided alternative methods because of their own reservations, capabilities, or school settings. Teachers need sufficient resources, a certain level of PCK, and support, to apply formative assessment (Haug \& Ødegaard, 2015).

The explanations that teachers gave for choosing certain teaching and assessment methods were related mainly to teachers' or students' abilities (about 90\%). As an example of student-related reasons, one of the teachers described his innovative and alternative assessment as follows: "I ask each one of my students in the same age group (about 200 students) to compose a question and answer it. All the 200 questions and answers are posted on the PADLET so everybody can access and study them. I create the tests from these questions." [1212023512068]. An example of a teacher-related argument is the response given by [2421112211116]: "All the teachers of the same age group and subject author the tests and quizzes jointly, saving time and effort for all of us."

Extrinsic reasons include guidelines from the Ministry of Education, logistics, and students' choices and capabilities, which explain more than $50 \%$ of the cases in which traditional methods are used. This contradicts research showing that alternative assessment is valued by students as part of the learning process (Miedijensky \& Tal, 2009; Mills \& Treagust, 2003). With respect to students' involvement in alternative assessment methods (Rached \& Grangeat, 2020), it is not compliant with the OECD vision of the future of education (Howells, 2018).

\section{Differences among a Variety of Teachers' Attributes}

We analyzed different attributes related to the type of school and how this affects teachers' perceptions. High school teachers use teaching methods that are more collaborative and open, while middle school teachers use worksheets, which are controlled and individualized. The difference in preferred methods can be explained by the matriculation examinations in high school. Interactive methods comprise about $30 \%$ of the material for the matriculation examinations, which requires use of alternative assessment (e.g., authentic assignments, inquiry projects, and portfolios). Therefore, high school teachers put the necessary effort into adhering to these policies (Barak \& Shakhman, 2008; Dori, 2003; Fischman et al., 2019). In high school, formative assessment methods are associated with summative assessments (Mandler et al., 2012). Middle school teachers try to prepare their students for the PISA $^{2}$ national tests, and therefore 'cover' all the material included in these tests. Primary school teachers usually have more flexibility and can better focus on studentcentered methods (Zlabkova et al., 2020). Middle school students can work more independently, while primary school students usually need closer guidance. Therefore, few primary school teachers selected tests with openended questions and experiment reports, and preferred a variety of other assessment methods, mainly studentcentered or combined methods, which enable a wider range of self-expression. Yet, some primary school teachers do not have enough content knowledge to apply effective formative assessment methods (Grob et al., 2019; Haug \& Ødegaard, 2015).

Students' conceptual understanding requires visualization and experience (Gale et al., 2016; Kop et al., 2020). In science teaching, experiments are part of the national, regional curriculum or learning program,

2 https:/ / www.oecd.org/pisa/ 
while in mathematics, experiments are not part of the learning culture. The choices made by mathematics teachers compared to those made by science teachers might represent this difference. Alternatively, this difference may indicate a lack of pedagogical knowledge regarding implementation of alternative teaching methods apart from worksheets and collaborative class work. For example, Marušić and Sliško (2012), who investigated teaching methods used by physics teachers, found that traditional teaching is not enough to improve students' reasoning, and integrating questioning and inquiry-based learning is more effective. Other researchers found that PBL can contribute to higher levels of conceptual understanding (Kohen et al., 2020).

In terms of experience, it seems the expert and novice teachers use similar methods that differ slightly from those of the experienced teachers. This might be explained by novice teachers' training and professional development programs, as described in recent studies (Buldur, 2017). Experienced teachers are more likely to suffer from burnout than novice and expert teachers. This burnout might cause a certain unwillingness to implement interactive teaching methods. Most of the expert teachers $(75 \%)$ with 15 or more years of experience are also subject coordinators, and as shown above, they tend to use more interactive teaching methods. Only $44 \%$ of the experienced teachers are also subject coordinators, thus they may be less inclined to use interactive teaching methods due to professional development issues and burnout, as found also in Rumschlag's study (2017). We found that novice teachers select structured methods that enable lesson scaffolding, such as slides and worksheets, while expert teachers select methods with higher levels of freedom for the students, including class discussions, workgroups, and experiments. This can be associated with the level of confidence teachers gain over the years (Fitzgerald, 2020). Furthermore, novice teachers need training on providing effective feedback to students (Ropohl \& Rönnebeck, 2019). In our study, inquiry and inquiry portfolios were selected by very few novice teachers, as found in Ress (2019), who explained that the novice teachers require more experience. Some methods require the confidence and experience that develops over time, but others simply require further training.

Regarding the majority vs. minority groups, some of the Arab minority schools are located in villages and have fewer resources than those of the majority population (Toren \& Iliyan, 2008). As described by other researchers, cultural differences have an impact on science teaching (Shaukat et al., 2020). Therefore, it is critical to foster awareness as a step towards equality, and to allocate the resources needed to close the gaps (Gindi \& Erlich-Ron, 2019). Although the minority groups might benefit from inquiry, which can overcome formal language barriers, it was selected only minimally by teachers in this group. Fully-guided experiments were selected ten times more often. This could be explained by cultural differences. Arab teachers' motivation is affected by their culture (Husny \& MassryHerzllah, 2016). The minority populations tend to be more confirmative by nature, and this is reflected in their education systems. For example, novice Arab teachers reported that students tend to reject new teaching methods and prefer passive learning methods in which the teacher is the source of knowledge (Toren \& Iliyan, 2008). Therefore, these teachers tend to prefer collaborative class work and experiments over class discussions. Using collaborative class work and experiments, students follow guidelines or complete exercises, while an open discussion might be interpreted as challenging the teacher's authority and is considered less acceptable (Abd-El-Khalick et al., 2004; Gindi \& Erlich-Ron, 2019). Collaborative class work also does not require an extra budget.

Considering the COVID-19 pandemic that has changed the education system, understanding teachers' background, knowledge, perceptions, and resources is most important. These parameters can determine how changes that are mandatory during a time of a pandemic can be assimilated by updating programs, and can become stimulators of future educational evolution.

\section{Research Limitations}

In this research, we investigated 125 STEM subject coordinators and teachers. However, we did not conduct class observations or collect any information from students, which should be done in future research. It is essential to study students' perceptions, as they are the beneficiaries of these methods (Bennett \& Hogarth, 2009; Bybee \& McCrae, 2011). However, even teachers' selfreports show a significant difference between optimal teaching and assessment methods, and the actual ones used by teachers. Another limitation is that we assessed only the teachers' statements on which methods they implemented, without referring to the effectiveness of the different teaching and assessment methods and the ways teachers apply them.

\section{Research Contribution}

This research is unique in the array of methods it compares and its presentation of the reasons for teachers' choices. Other studies have compared students' achievements or perceptions of two-three teaching or assessment methods (Abd-El-Khalick, 2004; Akkus et al., 2007; Barron, \& Darling-Hammond, 2008; Fitzgerald, 2020; Gale et al., 2016; Juuti et al., 2010; Mandler et al., 2012; Marušić, \& Sliško, 2012; Rees \& Roth, 2019; Tal el al., 2006). In our study, we compared STEM teachers' preferences regarding 14 teaching methods and eight assessment methods, as well as their perceptions of these methods. We also characterized 
differences between teachers from different school levels, subject matter, experience, and culture.

The methodological contribution stems from the five categories we identified: (a) passive teaching, (b) interactive teaching, (c) teaching methods that combine formative assessment methods, (d) traditional assessment, and (e) formative, alternative assessment methods. These categories are used in our paper to explain why teachers select one method over another, and can help explain the existing dissonance between the teachers' statements and what ultimately happens in class. This, in turn, can help find ways to overcome the obstacles that prevent teachers from implementing them in class.

From the practical perspective, as this research was conducted prior to the COVID-19 pandemic, it sets a baseline from which the educational system started. Last but not least, our study contributes to developing a better understanding of the teaching and assessment methods actually implemented in schools, and presents the gap between recommended and implemented methods.

\section{RECOMMENDATIONS}

Teaching and assessment methods have been developed and studied throughout the years. Student learning should be assessed in ways that suit the nature of the learning process. Learning should include formative assessment, which could lead to further learning (Birenbaum, et al. 2006; Wieman, 2014).

We recommend ensuring that when an educational reform or innovation is introduced, teachers receive sufficient and appropriate support that is well-suited to their strengths and abilities, as well as the necessary teaching resources (Corlu et al., 2014; Davis, 2002). Teachers need support for translating theory into practice, especially with respect to cultural differences (Toren \& Iliyan, 2008). For example, during professional development workshops, introducing mathematics teachers to relevant active learning methods, such as dynamic geometry, can enhance inquiry and experiment methods (Barabash, 2019; Soldano \& Arzarello, 2016; Stollman et al., 2020). Another example is training the teacher on how a field trip can reinforce mathematics education by putting the material into context. Educational reforms and professional development workshops should take into consideration the availability of resources in the teachers' schools (Sedawi et al., 2019).

Implementation of reforms can be more successful if teachers' perceptions are addressed and external issues are resolved by giving them adequate support. Teachers' self-efficacy is also crucial for the successful implementation of such reforms (Davis, 2002; Dogan et al., 2015; Evers et al., 2002).
The COVID-19 pandemic emphasized the need for enhancing teachers' online teaching skills. Standardized tests were found to be used most frequently. However, as they are less suitable for online assessment, teachers must deepen their knowledge regarding alternative assessment methods. It appears that subject coordinators' positive attitudes towards alternative assessment has not been passed on to the teachers. One way to deal with this is to create a teachers' community that focuses on assessment.

Specifically, curricula for pre-service STEM teachers should include an assessment workshop that focuses on theory and a variety of assessment methods. The preservice teachers will practice developing formative assessment tasks, and rubrics for evaluating the outcomes. Class discussions can focus on evaluation criteria.

Professional development workshops for in-service teachers should teach and exercise progressive assessment methods and ways to apply them. During these workshops, teachers should be exposed to several examples, evaluate actual students' deliverables, experience teaching and assessing their peers, and provide formative assessment for the workshop leaders.

We recommend that subject coordinators and school managers incentivize teachers who apply formative assessment methods. Schools can promote exposure days in which students' deliverables are presented. This will encourage teachers to use advanced assessment methods.

Stakeholders in the Ministry of Education can promote school seminars that encourage presentation of students' deliverables and recommend teachers' participation in the professional development of formative assessment methods.

With respect to all stakeholders, we recommend that online teaching and learning in STEM disciplines be emphasized and implemented with the appropriate resources, to prepare teachers and students for the $21^{\text {st }}$ century, in both times of routine and crisis.

\section{AUTHOR BIOGRAPHIES}

Effrat Akiri is a Doctoral student at the Technion, Israel Institute of Technology. In 2001, she completed a B.Sc. at the Department of Industrial Engineering and Management at Ben-Gurion University of the Negev. She received her Master of Business Administration (MBA) degree from the Technion in 2006, and her MA degree in group counseling in 2015. Her research is focused on novice and expert STEM teachers, their professional growth, and the relationships between the mentors and their mentees - the novice teachers. The research links a system perspective of teachers' professional growth, personal and interpersonal relationships, and the importance of active teaching methods and assessment for learning in STEM 
disciplines. Akiri's research was partially supported by the Irwin and Joan Jacobs Graduate School at the Technion.

Hrisilda Chris Matathia-Tor is an experienced teacher in special education and science and technology education in secondary schools. In 2015, she received her B.Sc. degree and in 2018 an M.Sc. degree, both in chemical education at the Faculty of Education of Science and Technology at the Technion - Israel Institute of Technology. Her research interests are innovative teaching methods and alternative assessment methods corresponding with the new set of skills required from the current generation of graduates. The research described in this paper was partially conducted during Hrisilda Chris Matathia-Tor's M.Sc. studies and partially supported by the Irwin and Joan Jacobs Graduate School at the Technion.

Yehudit Judy Dori is a Professor of Science Education at the Faculty of Education in Science and Technology, Technion - Israel Institute of Technology. Professor Dori holds a B.Sc. in Chemistry and Biochemistry from Hebrew University, a M.Sc. in Life Sciences and a Ph.D. in Science Education both from the Weizmann Institute of Science. She was Dean of the Faculty from 2015 to 2020. Previously, she was Dean of Continuing Education and External Studies at the Technion (2009-2013). She is a senior researcher at the Samuel Neaman Institute for national policy research, Haifa, Israel. She has been intermittently visiting Professor or visiting Scholar at Massachusetts Institute of Technology between 2000 and 2014, and during 2020. Her research interests encompass educational technology, teacher education, assessment, $21^{\text {st }}$ century STEM skills, and metacognition at the high school and university levels. Prof. Dori co-edited two books on cognition and metacognition in STEM education (2012 and 2018). Prof. Dori has mentored 75 graduate students and postdoctoral fellows, many of whom are faculty at universities and colleges in Israel and abroad. She received the 2020 NARST Distinguished Contributions to Science Education through Research Award -DCRA for her exceptional research contributions and strong national and international community engagements.

Author contributions: All authors have sufficiently contributed to the study, and agreed with the results and conclusions.

Funding: This work was partially supported by The Irwin and Joan Jacobs Graduate School at the Technion, Israel Institute of Technology, and by Haifa Municipality Partial Fellowships.

Declaration of interest: No potential conflict of interest was reported by the authors.

Acknowledgements: The authors thank the teachers who participated in this research and agreed to be interviewed and replied to the questionnaires.

\section{REFERENCES}

Abd-El-Khalick, F., Boujaoude, S., Duschl, R., Lederman, N. G., Mamlok-Naaman, R., Hofstein, A., Niaz, M.,
Treagust, D., \& Tuan, H. L. (2004). Inquiry in science education: International perspectives. Science Education, 88(3), 397-419. https://doi.org/ 10.1002/sce.10118

Aitken, N. (2016). Grading and Reporting Student Learning. In S. Scott, D. Scott, \& C. Webber (Eds.), Assessment in Education Implications for Leadership (pp. 231-260). Springer International Publishing. https://doi.org/10.1007/978-3-319-23398-7_10

Akkus, R., Gunel, M., \& Hand, B. (2007). Comparing an inquiry-based approach known as the science writing heuristic to traditional science teaching practices: Are there differences? International Journal of Science Education, 29(14), 1745-1765. https:/ / doi.org/10.1080/09500690601075629

Anghelache, V. (2013). Determinant factors of students' attitudes toward learning. Procedia - Social and Behavioral Sciences, 93, 478-482. https://doi.org/ 10.1016/j.sbspro.2013.09.223

Aslam, F., Adefila, A., \& Bagiya, Y. (2018). STEM outreach activities: an approach to teachers' professional development. Journal of Education for Teaching, 44(1), 58-70. https://doi.org/10.1080/ 02607476.2018.1422618

Avargil, S., Herscovitz, O., \& Dori, Y. J. (2012). Teaching thinking skills in context-based learning: Teachers' challenges and assessment knowledge. Journal of Science Education and Technology, 21, 207-225. https://doi.org/10.1007/s10956-011-9302-7

Avargil, S., Herscovitz, O., \& Dori, Y. J. (2013). Challenges in the transition to large-scale reform in chemical education. Thinking Skills and Creativity, 10, 189-207. https://doi.org/10.1016/j.tsc.2013.07. 008

Barabash, M. (2019). Dragging as a Geometric Construction Tool: Continuity Considerations Inspired by Students' Attempts. Digital Experiences in Mathematics Education, 5(2) 124-144. https://doi.org/10.1007/s40751-019-0050-2

Barak, M., \& Raz, E. (1998). Hot-air balloons: projectcentered study as a bridge between science and technology education. Science Education, 84(1), 2742. https:// doi.org/10.1002/(SICI)1098-237X(2000 01)84:1<27::AID-SCE3>3.0.CO;2-8

Barak, M., \& Shakhman, L. (2008). Reform-based science teaching: Teachers' instructional practices and conceptions. Eurasia Journal of Mathematics, Science $\mathcal{E}$ Technology Education, 4(1), 11-20. https:// doi.org/10.12973/ejmste/75301

Barnea, N., Dori, Y. J., \& Hofstein, A. (2010). Development and implementation of inquirybased and computerized-based laboratories: Reforming high school chemistry in Israel. Chemistry Education Research and Practice - CERP, 11, 218-228. https:/ / doi.org/10.1039/C005471M 
Barron, B., \& Darling-Hammond, L. (2008). Teaching for meaningful learning: A review of research on inquirybased and cooperative learning [Book Excerpt]. George Lucas Educational Foundation. http://www.edu topia.org/pdfs/edutopia-teaching-for-meaningful -learning.pdf

Bennett, J., \& Hogarth, S. (2009). Would you want to talk to a scientist at a party? High school students' attitudes to school science and to science. International Journal of Science Education, 31(14), 1975-1998.

https:/ / doi.org/10.1080/09500690802425581

Berlin, D. F., \& Lee, H. (2005). Integrating science and mathematics education: Historical analysis. School Science and Mathematics, 105(1), 15-24. https://doi. org/10.1111/j.1949-8594.2005.tb18032.x

Birenbaum, M., \& Rosenau, S. (2006). Assessment preferences, learning orientations, and learning strategies of pre-service and in-service teachers. Journal of Education for Teaching, 32(2), 213-225. https:/ / doi.org/10.1080/02607470600655300

Birenbaum, M., Breuer, K., Cascallar, E., Dochy, F., Dori, Y. J., Ridgway, J. \& Wiesemes, R. (2006). A learning integrated assessment system. In EARLI Series of Position Papers. Wiesemes, R., \& Nickmans, G. A. (Eds.). Educational Research Review, 1(1), 61-67. https:/ / doi.org/10.1016/j.edurev.2006.01.001

Bramwell Lalor, S., \& Rainford, M. (2016). Advanced level biology teachers' attitudes towards assessment and their engagement in assessment for learning. European Journal of Science and Mathematics Education, 4(3), 380-396. https:/ / doi.org/10.30935/ scimath $/ 9478$

Buchnik, Z. Natan, O., Rave, A., \& Hazan, O. (2014). Scientific and technological education in Israel: selected metrics for strategy building. Risk management due to the expected shortage in science and technology teachers in upper division. Samuel Neaman Institute for National Policy. https:/ / www.neaman.org.il/EN/ Selected-Indicators-Development-Risk-Manageme nt-Strategy (In Hebrew with Abstract in English).

Buldur, S. (2017). A longitudinal investigation of the preservice science teachers' beliefs about science teaching during a science teacher training programme. International Journal of Science Education, 39(1), 1-19. https://doi.org/10.1080/ 09500693.2016.1262084

Bybee, R., \& McCrae, B. (2011). Scientific Literacy and Student Attitudes: Perspectives from PISA 2006 science. International Journal of Science Education, 33(1), 7-26. https://doi.org/10.1080/09500693. 2010.518644

Chetcuti, D., \& Cutajar, C. (2014). Implementing Peer Assessment in a Post-Secondary (16-18) Physics Classroom. International Journal of Science Education,
36(18), 3101-3124. https://doi.org/10.1080/ 09500693.2014 .953621

Copur-Gencturk, Y., \& Thacker, I. (2020). A Comparison of Perceived and Observed Learning from Professional Development: Relationships Among Self-Reports, Direct Assessments, and Teacher Characteristics. Journal of Teacher Education, 72(2), 138-151.

https:/ / doi.org/10.1177/0022487119899101

Corlu, M., Capraro, R., \& Capraro, M. (2014). Introducing STEM education: Implications for educating our teachers for the age of innovation. Education and Science, 39(171), 74-85.

Creswell, J. W. (2014). Research Design: Qualitative, Quantitative and Mixed Methods Approaches (4th ed.). SAGE publications.

Darling-Hammond, L., Wilhoit, G., \& Pittenger, L. (2014). Accountability for college and career readiness: Developing a new paradigm. Education Policy Analysis Archives, 22(86), 2-38. https:/ / doi.org/10.14507/epaa.v22n86.2014

Davis, K. (2002). "Change Is Hard": What science teachers are telling us about reform and teacher learning of innovative practices. Science Education, 87(1), 3-30. https:/ / doi.org/10.1002/ sce.10037

Deeley, S. J. (2018). Using technology to facilitate effective assessment for learning and feedback in higher education. Assessment $\mathcal{E}$ Evaluation in Higher Education, 43(3), 439-448. https: / / doi.org/10.1080/ 02602938.2017 .1356906

Dogan, S., Pringle, R., \& Mesa, J. (2015). The impacts of professional learning communities on science teachers' knowledge, practice and student learning: a review. Professional Development in Education, 42(4), 569-588. https://doi.org/10.1080/19415257. 2015.1065899

Dori, Y. J. (2003). From nationwide standardized testing to school-based alternative embedded assessment in Israel: Students' performance in the "Matriculation 2000" Project. Journal of Research in Science Teaching, 40(1), 34-52. https://doi.org/ 10.1002/tea.10059

Dori, Y. J., Avargil, S., Kohen, Z., \& Saar, L. (2018). Context-based learning and metacognitive prompts for enhancing scientific text comprehension. International Journal of Science Education, 40(10), 1198-1220. https://doi.org/ 10.1080/09500693.2018.1470351

Dori, Y. J., Kohen, Z., \& Rizowy, B. (2020). Mathematics for Computer Science: A Flipped Classroom with an Optional Project. EURASIA Journal of Mathematics, Science and Technology Education, 16(12), em1915. https:/ / doi.org/10.29333/ ejmste/ 9149 
Ertmer, P. A. (1999). Addressing first- and second-order barriers to change: Strategies for technology integration. Educational Technology Research and Development, 47, 47-61. https://doi.org/10.1007/ BF02299597

Eskilsson, O., \& Hellden, G. (2003). A longitudinal study on 10-12-year-olds' conceptions of the transformations of matter. Chemistry Education Research and Practice, 4(3), 291-304. https:/ / doi.org /10.1039/B2RP90046G

Evers, W., Brouwers, A., \& Tomic, W. (2002). Burnout and self-efficacy: A study on teachers' beliefs when implementing an innovative educational system in the Netherlands. British Journal of Educational Psychology, 72(2), 227-243. https://doi.org/10.1348 /000709902158865

Fairbanks, C. M., Freedman, D., \& Kahn, C. (2000). The role of effective mentors in learning to teach. Journal of Teacher Education, 51(2), 102-112. https:/ / doi.org /10.1177/002248710005100204

Farchi T., \& Tubin D. (2016). Midlevel management as a link between the principal and school success. Studies in Education, (13/14), 80-101. University of Haifa. (in Hebrew). https://www.jstor.org/stable /26598414

Fischman, G. E., Topper, A. M., Silova, I., Goebel, J., \& Holloway, J. L. (2019). Examining the influence of international large-scale assessments on national education policies. Journal of Education Policy, 34(4), 470-499.

https:/ / doi.org/10.1080/02680939.2018.1460493

Fitzgerald, A. (2020). Out in the field: examining the role of school-based experiences in preparing primary pre-service teachers as confident and competent teachers of science. International Journal of Science Education, 42(2), 290-309. https:/ / doi.org/10.1080/ 09500693.2019.1710618

Foon Hew, K., \& Brush, T. (2007). Integrating technology into K-12 teaching and learning: Current knowledge gaps and recommendations for future research. Educational Technology Research and Development, 55, 223-252. https:/ / doi.org/10.1007/ s11423-006-9022-5

Gale, J., Wind, S., Koval, J., Dagosta, J., Ryan, M., \& Usselman, M. (2016). Simulation-based performance assessment: an innovative approach to exploring understanding of physical science concepts. International Journal of Science Education, 38(14), 2284-2302. https://doi.org/10.1080/ 09500693.2016.1236298

Gilbert, J. K. (2006). On the nature of "context" in chemical education. International Journal of Science Education, 28(9), 957-976. https:/ / doi.org/10.1080/ 09500690600702470
Gindi, S., \& Erlich-Ron, R. (2019). Bargaining with the system: A mixed-methods study of Arab teachers in Israel. International Journal of Intercultural Relations, 69, 44-53. https://doi.org/10.1016/ j.ijintrel.2018.12.004

Golafshani, N. (2003). Understanding reliability and validity in qualitative research. The Qualitative Report, 8(4), 597-606. https://doi.org/10.46743/ 2160-3715/2003.1870

Gozuyesil, E., \& Tanriseven, I. (2017). A Meta-analysis of the Effectiveness of Alternative Assessment Techniques. Eurasian Journal of Educational Research, 70, 37-56. https:/ / doi.org/10.14689/ejer.2017.70.3

Grob, R., Holmeier, M., \& Labudde, P. (2019). Analysing formal formative assessment activities in the context of inquiry at primary and upper secondary school in Switzerland. International Journal of Science Education, Published online: 8 October 2019. https:/ / doi.org/10.1080/09500693.2019.1663453

Harlen, W., \& James, M. (2006). Assessment and learning: Differences and relationships between formative and summative assessment. Assessment in Education: Principles, Policy E Practice, 4(3), 365379. https:/ / doi.org/10.1080/0969594970040304

Haug, B. S., \& Ødegaard, M. (2015). Formative assessment and teachers' sensitivity to student responses. International Journal of Science Education, 37(4), 629-654. https://doi.org/10.1080/09500693. 2014.1003262

Havnes, A., Smith, K., Dysthe, O., \& Ludvigsen, K. (2012). Formative assessment and feedback: Making learning visible. Studies in Educational Evaluation, 38(1), 21-27. https://doi.org/10.1016/ j.stueduc.2012.04.001

Hebel, F. L., Montpied, P., Tiberghien, A., \& Fontanieu, V. (2017). Sources of difficulty in assessment: example of PISA science items. International Journal of Science Education, 39(4), 468-487. https:/ / doi.org/10.1080/09500693.2017.1294784

Hodgson, Y., Varsavsky, C., \& Matthews, K. E. (2014). Assessment and teaching of science skills: whole of programme perceptions of graduating students. Assessment $\mathcal{E}$ Evaluation in Higher Education, 39(5), 515-530.

https:/ / doi.org/10.1080/02602938.2013.842539

Hofstein, A., Eilks, I., \& Bybee, R. (2012). Societal issues and their importance for contemporary science education-a pedagogical justification and the stateof-the-art in Israel, Germany, and the USA. International Journal of Science and Mathematics Education, 9, 1459-1483. https://doi.org/10.1007/ s10763-010-9273-9

Howells, K. (2018). The future of education and skills: education 2030: the future we want. OECD- Economic Co-operation and Development. http://www. 
oecd.org/education/2030/E2030\%20Position \% 20

Paper\%20(05.04.2018).pdf

Husny Arar, K., \& Massry-Herzllah, A. (2016). Motivation to teach: the case of Arab teachers in Israel. Educational Studies, 42(1), 19-35. https:/ / doi.org/10.1080/03055698.2015.1127136

Juuti, K., Lavonen, J., Uitto, A., Byman, R., \& Meisalo, V. (2010). Science teaching methods prefered by grade 9 students in Finland. International Journal of Science and Mathematics Education, 8, 611-632. https:/ / doi.org/10.1007/s10763-009-9177-8

Karpudewan, M., Ismail, Z., \& Roth, W. M. (2011). Ensuring sustainability of tomorrow through green chemistry integrated with sustainable development concepts (SDCs). Chemistry Education Research and Practice, 13, 120-127. https://doi.org/10.1039/ C1RP90066H

Kohen, Z., Herscovitz, O., \& Dori, Y. J. (2020). How to promote chemical literacy? On-line question posing and communicating with scientists. Chemistry Education Research and Practice - CERP, 21(1), 250266. https:/ / doi.org/10.1039/c9rp00134d

Kop, P., Janssen, F., Drijvers, P., \& van Driel, J. (2020). Promoting insight into algebraic formulas through graphing by hand. Mathematical Thinking and Learning, Published online: 25 May 2020. https:/ / doi.org/10.1080/10986065.2020.1765078

Krajcik, J. S., Blumenfeld, P. C., Marx, R. W., \& Soloway, E. (1994). A collaborative model for helping middle grade science teachers learn project-based instruction. The Elementary School Journal, 94(5), 483497. https:/ / doi.org/10.1086/461779

Lavi, R., Tal, M., \& Dori, Y. J. (2021). Perceptions of STEM alumni and students on developing 21st century skills through methods of teaching and learning. Studies in Educational Evaluation, 70. https:/ / doi.org/10.1016/j.stueduc.2021.101002

Leech, N. L., \& Onwuegbuzie, A. J. (2009). A typology of mixed methods research designs. Quality $\mathcal{E}$ Quantity, 43(2), 265-275. https://doi.org/10.1007/ s11135-007-9105-3

Lesseig, K., Nelson, T. H., Slavit, D., \& Seidel, R. A. (2016). Supporting middle school teachers' implementation of STEM design challenges. School Science and Mathematics, 116(4), 177-188. https://doi.org/10.1111/ssm.12172

Liu, M., Shi, Y., Pan, Z., Li, C., Pan, X., \& Lopez, F. (2020). Examining middle school teachers' implementation of a technology-enriched problem-based learning program: Motivational factors, challenges, and strategies. Journal of Research on Technology in Education, Published online: 16 June 2020. https:/ / doi.org/10.1080/15391523.2020.1768183

Mandler, D., Mamlok-Naaman, R., Blonder, R., Yayon, M., \& Hofstein, A. (2012). High-school chemistry teaching through environmentally oriented curricula. Chemistry Education Research and Practice, 13, 80-92. https://doi.org/10.1039/C1RP90071D

Marchis, I. (2011). Factors that influence secondary school students' attitude to mathematics. Procedia Social and Behavioral Sciences, 29, 786-793. https:/ / doi.org/10.1016/j.sbspro.2011.11.306

Marušić, M., \& Sliško, J. (2012). Influence of three different methods of teaching physics on the gain in students' development of reasoning. International Journal of Science Education, 34(2), 301-326. https:/ / doi.org/10.1080/09500693.2011.582522

Miedijensky, S., \& Tal, T. (2009). Embedded Assessment in Project-based Science Courses for the Gifted: Insights to inform teaching all students. International Journal of Science Education, 31(18), 2411-2435.

https://doi.org/10.1080/09500690802389597

Mills, J. E., \& Treagust, D. F. (2003). Engineering education - Is problem-based or project-based learning the answer. Australasian journal of engineering education, 3(2), 2-16. http:/ / www.aaee. com.au/journal/2003/mills_treagust03.pdf

Moore, J. L. (1992). The Role of the Science Co-ordinator in Primary Schools. A Survey of Headteachers' Views. School Organization, 12(1), 7-15. https://doi.org/ $10.1080 / 0260136920120102$

Muema, J., Mulwa, D., \& Mailu, S. (2018). Relationship between teaching method and students' performance in Mathematics in public secondary schools in Dadaab sub country, Garissa country; Kenya. IOSR Journal of Research and Method of Education, 8(5), 59-63. https://doi.org/10.9790/ 7388-0805052832

Nachmias, R., Mioduser, D., \& Forkosh-Baruch, A. (2010). ICT use in education: Different uptake and practice in Hebrew-speaking and Arabic-speaking schools in Israel. Journal of Computer Assisted Learning, 26(6), 492-506. https://doi.org/10.1111/ j.1365-2729.2010.00374.x

Namdar, B., \& Shen, J. (2015). Modeling-Oriented Assessment in K-12 Science Education: A synthesis of research from 1980 to 2013 and new directions. International Journal of Science Education, 37(7), 9931023.

https:/ / doi.org/10.1080/09500693.2015.1012185

National Research Council (NRC). (2012). A framework for k-12 science education: Practices, crosscutting concepts, and core ideas. The National Academy Press. https:/ / doi.org/10.1080/0260136920120102

Neumann K. (2015) Formative Assessment. In R. Gunstone (Ed.), Encyclopedia of Science Education. Springer.

Osborne, J. (2014). Teaching scientific practices: Meeting the challenge of change. Journal of Science Teacher 
Education, 25(2), 177-196. https:/ / doi.org/10.1007/ s10972-014-9384-1

Rached, E., \& Grangeat, M. (2020). French teachers' informal formative assessment in the context of inquiry-based learning. International Journal of Science Education, Published online: 19 March 2020. https:/ / doi.org/10.1080/09500693.2020.1740818

Rees, C. A., \& Roth, W. M. (2019). Discourse forms in a classroom transitioning to student-centred scientific inquiry through co-teaching. International Journal of Science Education, 41(5), 586-606. https:// doi.org/10.1080/09500693.2019.1571649

Ropohl, M., \& Rönnebeck, S. (2019). Making learning effective - quantity and quality of pre-service. International Journal of Science Education, 41(15), 2156-2176.

https://doi.org/10.1080/09500693.2019.1663452

Rumschlag, K. E. (2017). Teacher Burnout: A Quantitative Analysis of Emotional Exhaustion, Personal Accomplishment, and Depersonalization. International Management Review, 13(1), 22-37. https:// doi.org/10.15390/EB.2014.2515

Russ, R. S., Coffey, J. E., Hammer, D., \& Hutchison, P. (2008). Making classroom assessment more accountable to scientific reasoning: A case for attending to mechanistic thinking. Science Studies and Science Education, 93(5), 875-891. https://doi.org/10.1002/ sce.20320

Schallies, M., \& Eysel, C. (2004). Learning beyond school: Establishing a laboratory for sustainable education. Chemistry Education Research and Practice, 5(5), 111126. https:// doi.org/10.1039/B4RP90015D

Schwerdt, G., \& Wuppermann, A. (2011). Is traditional teaching really all that bad? A within-student between-subject approach. Economics of Education Review, 30(2), 365-379. https://doi.org/10.1016/ j.econedurev.2010.11.005

Sedawi, W., Assaraf, O. B. Z., \& Reiss, M. J. (2019). Regenerating Our Place: Fostering a Sense of Place Through Rehabilitation and Place-Based Education. Research in Science Education, Published online: 19 November 2019. https://doi.org/10.1007/s11165-019-09903-y

Shaukat, S., Vishnumolakala, V. R., \& Alghamdi, A. K. H. (2020). Science Teachers' Perceptions of Personal Science Efficacy Beliefs and Science Teaching in Saudi Arabia, Pakistan, and the United Arab Emirates. EURASIA Journal of Mathematics, Science and Technology Education, 16(8), em1866. https:// doi.org/10.29333/ejmste/8290

Soldano, C., \& Arzarello, F. (2016). Learning with touchscreen devices: game strategies to improve geometric thinking. Mathematics Education Research Journal, 28, 9-30. https://doi.org/10.1007/s13394015-0166-7
Stender, A., Schwichow, M., Zimmerman, C., \& Härtig, H. (2018). Making inquiry-based science learning visible: the influence of CVS and cognitive skills on content knowledge learning in guided inquiry. International Journal of Science Education, 40(15), 1812-1831.

https:/ / doi.org/10.1080/09500693.2018.1504346

Stollman, S., Meirink, J., Westenberg, M., \& Van Driel, J. (2020). Teachers' learning and sense-making processes in the context of an innovation: a two year follow-up study. Professional Development in Education, Published online: 27 Mar 2020. https:/ / doi.org/10.1080/19415257.2020.1744683

Tal, T., Krajcik, J., \& Blumenfeld, P. (2006). Urban Schools' Teachers Enacting Project-Based Science. Journal of Research in Science Teaching, 43(7), 722-745. https:// doi.org/10.1002/tea.20102

Toren, Z., \& Iliyan, S. (2008). The problems of the beginning teacher in the Arab schools in Israel. Teaching and Teacher Education, 24(4), 1041-1056. https:/ / doi.org/10.1016/j.tate.2007.11.009

Tsybulsky, D. (2018). Comparing the impact of two science-as-inquiry methods on the NOS understanding of high-school biology students. Science \& Education, 27(7), 661-683. https:// doi.org/10.1007/s11191-018-0001-0

Umugiraneza, O., Bansilal, S., \& North, D. (2017). Exploring teachers' practices in teaching Mathematics and Statistics in KwaZulu-Natal schools. South African Journal of Education, 37(2), 1306. https:// doi.org/10.15700/saje.v37n2a1306

Usher, M., \& Barak, M. (2020). Team diversity as a predictor of innovation in projects of online and face-to-face learners. Computers \& Education, 144, 103702.

https://doi.org/10.1016/j.compedu.2019.103702

Wang, X. (2013). Why students choose STEM majors: Motivation, high school learning, and postsecondary context of support. American Educational Research Journal, 50(5), 1081-1121. https://doi.org/10.3102/0002831213488622

Wengrowicz, N., Dori, Y. J., \& Dori, D. (2017). Metaassessment in a project-based systems engineering course. Assessment \& Evaluation in Higher Education, 42(4), 607-624. https://doi.org/10.1080/02602938. 2016.1173648

Westbroek, H. B., van Rens, L., van den Berg, E., \& Janssen, F. (2020). A practical approach to assessment for learning and differentiated instruction. International Journal of Science Education, 42(6), 955-976. https://doi.org/10.1080/09500693. 2020.1744044

Wieman, C. (2014). Large-scale comparison of science teaching methods sends clear message. Proceedings 
of the National Academy of Sciences, 111(23), 83198320. https:// doi.org/10.1073/pnas.1407304111

Wiliam, D. (2011). What is assessment for learning? Studies in Educational Evaluation, 37(1), 3-14. https:// doi.org/10.1016/j.stueduc.2011.03.001

Wong, V. J. (2018). The relationship between school science and mathematics education (Doctoral dissertation, King's College London). https://kclpure.kcl.ac.uk /portal/

Worlitz, J., Branke, M., Troike, M., Hettling, L., \& Woll, R. (2018, December). The contribution of learning, teaching and assessment activities to the development of 21st century STEM competencies. In 2018 IEEE international conference on teaching, assessment, and learning for engineering (TALE) (pp. 316-321). IEEE. https://doi.org/10.1109/TALE. 2018.8615320

Zee, M., \& Koomen, H. (2016). Teacher self-efficacy and its effects on classroom processes, student academic adjustment, and teacher well-being: A
Synthesis of 40 Years of Research. Review of Educational Research, 86(4), 981-1015. https://doi.org/10.3102/0034654315626801

Zezekwa, N., \& Nkopodi, N. (2020). Physics teachers' views and practices on the assessment of students' practical work skills. Eurasia Journal of Mathematics, Science and Technology Education, 16(8), em1865. https:// doi.org/10.29333/ejmste/8289

Zlabkova, I., Petr, J., Stuchlikova, I., Rokos, L., \& Hospesova, A. (2020). Development of teachers' perspective on formative peer assessment. International Journal of Science Education, Published online: 18 Jan 2020. https://doi.org/10.1080/ 09500693.2020.1713418

Zohar, A., \& Nemet, F. (2002). Fostering students' knowledge and argumentation skills through dilemmas in human genetics. Journal of Research in Science Teaching, 39(1), 35-62. https://doi.org/ 10.1002/tea.10008 


\section{APPENDIX A}

\section{Factor Loadings for Participants' Perceptions of Teaching and Assessment Methods and School Resources}

Perceptions towards teaching and assessment methods and school resources $(\mathrm{N}=116)$ Factor 1 Factor 2 Factor 3

(1) In the school I teach at, teachers are encouraged to innovate their assessment methods

(10) In the school I teach at, teachers are encouraged to innovate their teaching methods

\section{.739}

(11) In the school I teach at, efforts are made to integrate educational technologies

(13) In the school I teach at, teachers are encouraged to use alternative assessment

(15) In the school I teach at, alternative assessment is done at least once a year

(12) In the school I teach at, the students can influence the ways in which they are assessed

.706

.670

(6) In the school I teach at, the students can influence the contents they are taught

.648

(4) In the school I teach at, the students often work in groups

.438

(2) In the school I teach at, the students learn the science disciplines in laboratories

.392

(5) In the school I teach at, the assessment is done in traditional methods

(16) In the school I teach at, the students are assessed by standardized tests only

(9) In the school I teach at, students are expected to work at home

(19) In my opinion, traditional assessment methods (standardized tests) are better and the most efficient

(21) In my opinion, high achieving students prefer standardized tests

(20) In my opinion, students prefer lectures rather than interactive teaching methods

(17) In my opinion, students prefer alternative assessment methods - statement reversed

(18) In my opinion, variety is the most important factor when integrating different teaching methods

(14) In the school I teach at, there is at least one computer farm

(8) In the school I teach at, teachers are encouraged to participate in teacher training programs

(7) In the school I teach at, most classes are equipped with a computer for the teacher

(3) In the school I teach at, most classes are equipped with a digital projector

${ }^{\mathrm{b}}$ Questions were grouped according to content and context rather than factor loading

\section{http://www.ejmste.com}

